\title{
Effect of the Dietary Inclusion of Full Fat Canola Seed on Performance of Quails
}

\author{
Serdar ERATAK ${ }^{1}$, Metin ÇABUK ${ }^{1}$
}

${ }^{1}$ Department of Poultry Science, Akhisar Vocational School of Manisa Celal Bayar University, Turkey

${ }^{1}$ Department of Poultry Science, Akhisar Vocational School of Manisa Celal Bayar University, Turkey

\begin{abstract}
:
This experiment was conducted to study the effects of different levels of full fat canola seed low in glucosinolate and erucic acid on the performance of 336 day old quail (Coturnix coturnix japonica). The experiment was performed in a completely randomize design with three treatment and four replicates for each treatment. The experimental treatment included 5 and $10 \%$ full fat canola seed in diet and fed to quail from 1 to 42 days of age. All of the experimental diets were iso-caloric and iso-nitrogenous. The mean total body weight was not significantly influenced by canola seed inclusion levels. But feed intake was significantly increased by supplementation of $10 \%$ full fat canola seed to the diet. Adding $10 \%$ full fat canola seed to the quail diet caused worsening in feed efficiency. Percentage of liver, proventriculus, gizzard, carcass to body weight was not significantly affected by canola seed inclusion levels. But small intestine rate was significantly increased by supplementation of $10 \%$ full fat canola seed to the diet. As a result, it is possible to say that the full fat canola seed low in glicosinolate and erucic acid content could be used up to $10 \%$ level in quails' diet.
\end{abstract}

Key words: Full fat canola, quail, performance, internal organs weight

\section{Introduction}

Since soya bean and corn, largely used as protein and energy supplementation in poultry rations, are expensive it is necessary to investigate new feed resources. Thanks to the breeding researches on rapeseed the contents of erucic acid and glikozinolat, which are antinutritive factors, of the rapeseed were reduced to the levels that are not harmful for animal feeding. This fact made rapeseed fat and its palp enable to be used in animal feeding [1,2]. Animal breeding studies revealed that erucic acid content of rapeseed fat was reduced from $50 \%$ to $1 \%$; glikozinolat content of it reduced from $150 \mu \mathrm{mol} / \mathrm{g}$ ' to $30 \mu \mathrm{mol} / \mathrm{g}$. The phenomena that refers the reduced content of these items in rapeseed is named as ' 00 (double zero varieties)' [3,1,2,4]. Accordingly, '0' erucic acid content refers to low erucic acid canola seed; '00' refers to both low glikozinolat and erucic acid containing canola seed.

There has been a rapid increase in canola production areas in EU countries. It is known that the origin of rapeseed is Mediterranean region however, its production in Turkey is scarce. Despite the findings mentioned above rapeseed is being used only with limited amounts in Turkey due to the concerns that it may affect animal feeding adversely. The main sources of these concerns are the results of the studies done on animals using high glikozinolat containing rapeseed meal that demonstrating its adverse effects. The studies that used both low glikozinolat and erucic acid containing full fat canola seed on poultry are scarce. Additionally, there has not been an agreement in the findings regarding to performance parameters in these studies.

The aim of this study was to determine the effects of different levels of full fat canola seed on performance of quail.

\section{Materials and Methods}

In the study, 336 mixed sexes, a day quail (Coturnix coturnix japonica) were used. The study was performed in a completely randomize design with three treatment and four replicates for each treatment. Study lasted for six weeks. Each replicate had 28 quails. The composition and nutrients of the concentrate used in the 
study were given in Table 1. Nutrients of full fat canola seed used in the study were given in Table 2; Diets were prepared as iso-caloric and iso-nitrogenous and fed ad-libitum for 6 weeks. Diets of the groups were as follow: Group1 (control): Corn-soya based concentrate, no canola seed; Group 2: contains 5\% full fat canola seed in addition to corn-soya based concentrate; Group 3: contains 10\% full fat canola seed in addition to corn-soya based concentrate.

Body weight and feed consumption values were recorded weekly; animal deaths recorded daily. At the end of sixth week 16 quails from each group were slaughtered and carcass, small intestine, proventriculus, gizzard, liver and internal organs weights were recorded. Carcass yield was determined by dividing carcass weight to body weight; internal organs ratios were determined by dividing organs weight to live weight. The experimental diets and canola seed were also analyzed for dry matter, starch, sucrose, crude protein, ether extract, and crude ash using the method of the Association of German Agricultural Analysis and Research Institutes (VDLUFA) [5]. Data were analyzed using SAS program [6].

Table 1. Ingredient and nutritive contents of diets

\begin{tabular}{|c|c|c|c|}
\hline \multirow[t]{2}{*}{ Ingredient } & & \multirow{2}{*}{ Canola seed, $5 \%$} & \multirow[b]{2}{*}{ Canola seed, $10 \%$} \\
\hline & Control & & \\
\hline Maize & 51.77 & 49.13 & 46.53 \\
\hline Soybean meal (0.48 CP) & 32.70 & 34.75 & 36.84 \\
\hline Full fat canola seed $(00)$ & 0.00 & 5.00 & 10.00 \\
\hline Full fat soybean & $10 . .00$ & 5.00 & 0.00 \\
\hline Ground limestone & 2.47 & 3.26 & 3.21 \\
\hline Dicalcium phosphate & 2.26 & 2.06 & 2.62 \\
\hline Salt & 0.25 & 0.25 & 0.25 \\
\hline Vitamin-Mineral premix* & 0.30 & 0.30 & 0.30 \\
\hline DL-methionine & 0.15 & 0.15 & 0.15 \\
\hline Lysine & 0.10 & 0.10 & 0.10 \\
\hline \multirow[t]{2}{*}{ Total } & 100.00 & 100.00 & 100.00 \\
\hline & \multicolumn{3}{|c|}{ Calculated nutrient contents, $\%$} \\
\hline Dry matter & 91.81 & 91.93 & 92.2 \\
\hline Crude Protein $(\mathrm{CP})$ & 24.00 & 24.00 & 24.00 \\
\hline Crude fiber & 2.47 & 2.67 & 2.87 \\
\hline Crude ash & 7.98 & 8.69 & 9.20 \\
\hline Ether extract & 2.36 & 4.99 & 6.01 \\
\hline Methionine + cystine & 0.96 & 0.95 & 0.97 \\
\hline Lysine & 1.50 & 1.49 & 1.50 \\
\hline Calcium & 1.30 & 1.34 & 1.41 \\
\hline Phosphorus, total & 0.81 & 0.79 & 0.82 \\
\hline Phosphorus, available & 0.60 & 0.60 & 0.61 \\
\hline Metabolisable Energy, kcal/kg & 2930 & 2930 & 2930 \\
\hline
\end{tabular}

*Vitamin-mineral premix (kg/diet): vitamin A, $12000 \mathrm{IU}$; vitamin $\mathrm{D}_{3}, 1500 \mathrm{IU}$; vitamin $\mathrm{E}, 30 \mathrm{mg}$; vitamin $\mathrm{K}_{3}, 5 \mathrm{mg}$; vitamin $\mathrm{B}_{1}, 3 \mathrm{mg}$; vitamin $\mathrm{B}_{2}, 6 \mathrm{mg}$; vitamin $\mathrm{B}_{6}, 5 \mathrm{mg}$; vitamin $\mathrm{B}_{12}, 0.03 \mathrm{mg}$; nicotine amid, $40 \mathrm{mg}$; calcium-D-pantothenate, $10 \mathrm{mg}$; Folic acid, $0.75 \mathrm{mg}$; D-Biotin, 0.075 mg; Choline Chloride, 375 mg; antioxidant, 10 mg., Mn, 80 mg; Fe, 80 mg; Zn, 60 mg; Cu, 8 mg; I, 0.5 mg; Co, 0.2 mg; Se, 0.15 mg.

Table 2. Nutrient content of canola seed used in the experiment

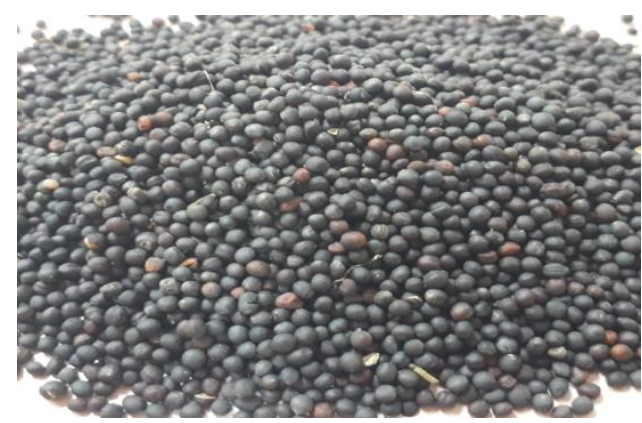

\begin{tabular}{|l|c|}
\hline Nutrients, Analyzed & $\%$ \\
\hline Dry matter, \% & 94.80 \\
\hline Crude protein, \% & 19.44 \\
\hline Ether extract, \% & 41.90 \\
\hline Starch, \% & 3.80 \\
\hline Sucrose, $\%$ & 6.10 \\
\hline Crude ash,\% & 4.00 \\
\hline Metabolisable Energy, kcal/kg & 4776 \\
\hline
\end{tabular}

Figure 1: Canola seed used in the experiment 


\section{Results and Discussions}

Body weight, feed consumption, feed conversion ratio and death ratios were given in Table 3. Addition of $5 \%$ or $10 \%$ of full fat canola seed to diet did not affect body weight $(\mathrm{P}>0.05)$. Highest body weight $(178.69$ g) was determined in $42^{\text {nd }}$ day in control group followed by $10 \%$ (177.6 g) and $5 \%$ (174.89) canola added groups. These findings were in agreement with findings of Nwokolo et al. [7], Ajuyah et al. [8], Zeb et al. (9), Brettenbach [2] and Talebali and Farzinpour [10] and Meng et al. [11]. All of these studies reported that addition of $10 \%$ full fat canola seed to quail diet did not adversely affect body weight of quails.

Table 3. The effect of full fat canola seed on body weight, feed intake and the FCR ( $\mathrm{g}$ feed/g gain) of the quail.

\begin{tabular}{|l|c|c|c|c|c|c|c|c|}
\hline \multicolumn{1}{|c|}{ Treatments } & \multicolumn{3}{c|}{ Body weight, g } & \multicolumn{2}{c|}{ Feed intake, g } & \multicolumn{2}{c|}{ FCR, g feed/g gain } & Mortality, \% \\
\hline \multicolumn{1}{|c|}{ Age, day } & 1 & 21 & 42 & 21 & 42 & 21 & 42 & 42 \\
\hline Control & 6.73 & 83.55 & 178.69 & $178.86^{\mathrm{b}}$ & $561.23^{\mathrm{b}}$ & $2.33^{\mathrm{b}}$ & $3.26^{\mathrm{b}}$ & 5.37 \\
\hline Canola seed, 5\% & 6.74 & 81.95 & 174.89 & $179.52^{\mathrm{b}}$ & $560.59^{\mathrm{b}}$ & $2.39^{\mathrm{a}}$ & $3.33^{\mathrm{ab}}$ & 4.30 \\
\hline Canola seed, 10\% & 6.85 & 84.51 & 177.64 & $186.20^{\mathrm{a}}$ & $587.50^{\mathrm{a}}$ & $2.40^{\mathrm{a}}$ & $3.44^{\mathrm{a}}$ & 4.30 \\
\hline SEM pooled & 0.4 & 1.27 & 1.61 & 2.64 & 6.83 & 0.03 & 0.03 & 1.36 \\
\hline Probabilty & 0.320 & 0.383 & 0.167 & 0.012 & 0.004 & 0.036 & 0.012 & 0.765 \\
\hline
\end{tabular}

a, b: Differences between averages with different letters in the columns are important $(\mathrm{P}<0.05)$

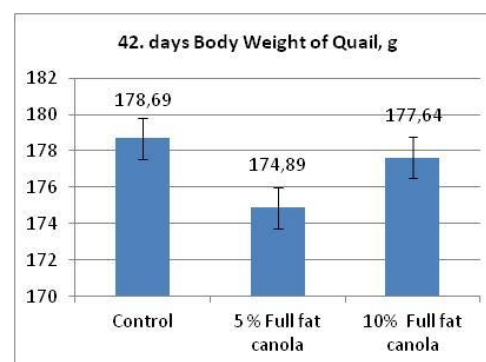

Graphic 1: Body weight of Quail
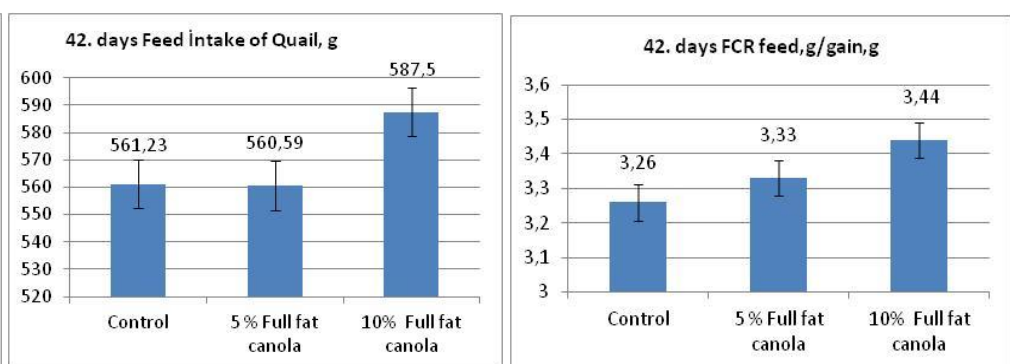

Graphic 2: Feed Intake of Quail Graphic 3: Feed conversion ratio of Quail

Addition of $5 \%$ canola to diet produced similar results for feed consumption with control group whereas $10 \%$ canola addition increased feed consumption $(\mathrm{P}<0.01)$. These findings were similar to those found in the study of Talebali and Farzinpour [10]. In the mentioned broiler study these researcher determined that adding $9 \%$ or more than this amount of canola to the diet increased feed consumption. Contrary to these findings, Brettenbach [2] reported that adding canola to the diet decreased feed consumption.

Feed conversion ratios were found different among groups $(\mathrm{P}<0.01)$. Addition of either 5 or $10 \%$ canola to the diet adversely affected feed conversion ratio at $21^{\text {st }}$ day. Adding $5 \%$ canola seed to the diet did not affect feed conversion ratio at $42^{\text {nd }}$ day,

however, adding $10 \%$ full fat canola seed to the quail diet caused worsening in feed conversion ratio. These feed conversion ratio findings were in agreement with those reported by Talebali and Farzinpour [10] for broilers. Similarly, Meng et al. [11] found that adding 20\% canola to the diet adversely affected feed conversion ratio in broilers. Contrary to this, Brettenbach [2] reported that when full fat canola addition was at $16.9 \%$ level feed conversion ratio reached at optimum levels in broilers. Adding full fat canola seed to the diet did not affect death ratio of quails..

Finding regarding to the effects of adding full fat canola seed to the diet on carcass yield, liver, proventriculus, gizzard weight ratio were given in Table 4. Carcass yield, intestine, liver, proventriculus, gizzard weight ratios were not affected from full fat canola seed inclusion to the diet, whereas, intestine ratio increased with canola inclusion $(\mathrm{P}<0.01)$. Findings regarding to liver weight determined in the present study are in agreement with those reported by Talebali and Farzinpour [10] that adding canola to the diet up to $12 \%$ did not affect liver weight. 
Table 4. The effect of full fat canola seed on carcass yield and relative weight (\% body weight) of some internal organs of quails

\begin{tabular}{|l|c|c|c|c|c|}
\hline Treatments/ Parameter & Control & Canola, 5\% & Canola, 10\% & SEM pooled & $\begin{array}{c}\text { Probability } \\
(\mathrm{P}<0,05)\end{array}$ \\
\hline Carcass yield, \% & 74.14 & 74.24 & 74.18 & 0.42 & 0.4998 \\
\hline Small intestine rate, \% & $3.38^{\mathrm{b}}$ & $3.62^{\mathrm{ab}}$ & $3.82^{\mathrm{a}}$ & 0.10 & 0.0164 \\
\hline Liver rate, \% & 1.74 & 1.86 & 1.93 & 0.06 & 0.0870 \\
\hline Gizzard rate, \% & 2.26 & 2.39 & 2.42 & 0.07 & 0.1820 \\
\hline Proventriculus rate, \% & 0.42 & 0.46 & 0.42 & 0.01 & 0.0813 \\
\hline
\end{tabular}

a, b: Differences between averages with different letters are important $(\mathrm{P}<0.05)$.

\section{Conclusions}

In the present study it was determined that adding $5 \%$ or $10 \%$ full fat canola seed to the quail diet did not adversely affect body weight increase. Nevertheless, adding $10 \%$ full fat canola seed to the quail diet increased feed consumption and caused worsening in feed efficiency. Adding $10 \%$ full fat canola seed to the quail diet did not affect carcass yield, intestine, liver, proventriculus and gizzard weight ratios, but increased intestine ratio. Although findings in the present study indicate that low erucic acid and glikozinolat containing full fat canola seed could be included in the quail diets up to $10 \%$, this issue warrants further research.

\section{References}

[1] [1] Leeson, S. and J.D. Summers. 1997. Commercial Poultry Nutrition (second edition). University Boks. Guelp, Ontario, Canada

[2] [2] Brettenbach L. 2005. The influence of processing of lupins and canola on apparent metabolizable energy and broiler performance. Master of Science in Agriculture. Stellenbosch University. South Africa

[3] [3] Alçicek, A. 1995. New views on the use of low canola meal in animal nutrition. E. Ü. Ziraat Fak. Dergisi. 35: 1. 207-214

[4] [4] Nicholas, Z, 2009. Gene modification adds value to canola seed (Alberta and shanghai partner to cut pollution). Feed Tech, volume 13 Number. 2: 18-20

[5] [5] Naumann, C. and Bassler, R. "Chemical analyses of feed stuff," 3rd Ed, VDLUFA(the Association of German Agricultural Analytic and Research Institutes)- Press. Darmstadt, Germany, 1993.

[6] [6] Sas institue, 1995. Sas User's guide: statistics edition. Sas inc. NC., USA

[7] [7] Nwokolo E and J. Sim, 1989. Barley and full fat canola seed in broiler diets. Poult. Sci., 68:137480

[8] Ajuyah, A. O., K. H. Lee, R. T. Hardin, and J. S. Sim. 1991. Changes in the yield and in the fatty acid composition of whole carcass and selected meat portions of broiler chickens fed full-fat oil seeds. Poult. Sci. 70:2304-2314.

[9] Zeb, A., A. Satter and U. Meulen, 1999. Effect of feeding different levels of rapeseed meal on the performance of broiler chickens. Archive Fuer Gefluegelkund, 63: 77-81

[10] Talebali H. and A. Farzinpour. 2005, Effect of different levels of full-fat canola seed as a replacement for soybean meal on the performance of broiler chickens. Int. J. of Poult. Sci., 4 (12): 982-985

[11] Meng, X., Slominski, B. A., Campbell, L. D., Guenter, W. and Jones, O. 2006. The use of enzyme technology for improved energy utilization from full fat oilseeds. Part 1: Canola Seed. Poult. Sci., 85:1025-1030 